\title{
ENVIRONMENTAL PARAMETERS AND RELATIONSHIPS WITH COVID-19 CASES IN CENTRAL SOUTH AMERICA
}

\author{
Thais Costa Brunellia, ${ }^{\mathrm{a},(1)}$, Sophia Paiva ${ }^{\mathrm{a}}$, Angélica Yara Siqueira ${ }^{\mathrm{a}}$, Cleyton Elizeu Santana ${ }^{\mathrm{a}}$, Luís Otávio Curvo ${ }^{\mathrm{a}}$, João Basso \\ Marques $^{\mathrm{a}}$ and Thiago Rangel Rodrigues ${ }^{\mathrm{b}}$ \\ aUniversidade Federal do Mato Grosso, 78060-900 Cuiabá - MT, Brasil \\ 'Instituto de Física, Universidade Federal do Mato Grosso do Sul, 79070-900 Campo Grande - MS, Brasil \\ Recebido em 09/02/2021; aceito em 31/05/2021; publicado na web em 22/06/2021
}

\begin{abstract}
This work aims to evaluate the possible relations between the confirmed daily cases of COVID-19 and the environmental parameters for the Cuiabá-Várzea Grande conurbation in the state of Mato Grosso, Brazil. The data sets used to cover the rainy-dry periods, from January to December 2020, were achieved from a database of government institutions, and processed through the Spearman correlation test. Our results showed that atmospheric pressure and fire radiative power has a significant positive correlation, suggesting that these parameters favor the transmission of COVID-19. On the other hand, the relative humidity of the air and the total column of water vapor showed a significant negative correlation with the number of confirmed daily cases of COVID-19, which indicates that the water vapor present in the atmosphere acts in the regulation of virus transmission. Thus, taking into account the results obtained, there is a need for collaborative policies and measures among the three spheres of executive power in Brazil, to act in the surveillance of fire cases, which can favor the transmission of COVID-19. In addition, prevention and protection measures aimed at reducing the spread of coronavirus continue to be indispensable.
\end{abstract}

Keywords: coronavirus; environmental parameters; aerosol; water vapor; fire.

\section{INTRODUCTION}

Pandemic events have already occurred in history, such as the bubonic plague crisis, triggered in the middle ages by the bacterium Yersinia pestis, or the Spanish flu crisis, which occurred in the early twentieth century, caused by an influenza virus. ${ }^{1}$ Recently, at the end of 2019, a wave of cases of acute respiratory syndrome that have begun in Wuhan city, China, and a few months, a pandemic reached Eurasia, Oceania, Africa, and America., ${ }^{2,3}$ Considering the severity of the disease, research centers, technological institutes, and governments around the world have joined forces to study and understand the causes, means of contagion, and transmission between people and animals infected by the previously unknown Coronavirus. ${ }^{4-6}$ Diseases of pathogenic characteristics, caused by viruses of the family Coronaviridae, when associated with other diseases have a lethality rate of 36\%.7 In March 2020, the World Health Organization (WHO) categorized the new disease as Severe Acute Respiratory Syndrome by Coronavirus - SARS-Cov-2 (COVID-19). Since then, we have experienced a new global pandemic that affects the health sectors with political, economic, and environmental consequences. ${ }^{8}$

In an attempt to understand the dynamics of transmission and the permanence of the COVID-19 virus on different surfaces, the work of Van Doremalen opened new possibilities to the scientific community and guided how to mitigate the destructive effects caused by the respective respiratory disease. This work was relevant to lead the decisions because until then, there were no studies that related the transmission and time of activity of SARS-Cov-2 in aerosols and its consequences. Studies relating to atmospheric physics and parasitic biology typify some factors that can affect the survival of airborne pathogens, the bioaerosols. Was analyzed the process of activity and half-life of both SARS-CoV-2 and SARS-1 on five transmission surfaces, among them, the aerosols. The results showed that the SARS-CoV-2 (COVID-19), when in a state of suspension, in the form

*e-mail: thais12@fisica.ufmt.br of an aerosol, has a time of activity and permanence of up to $3 \mathrm{~h}$, it is a time of viral activity sufficient for aerial infection between hosts. ${ }^{9}$

Is indispensable that society and decision-makers know the factors that influence and are associated with the spreading and infection by COVID-19 in urban centers. As it is a disease that started in the Northern Hemisphere (HN), many initial studies considered that the countries of the Southern Hemisphere (HS) would be exempted from the process of pronounced transmission, as experienced in the $\mathrm{HN}$, due to the different climatic conditions between the hemispheres. ${ }^{10}$ The temperature and relative humidity of the air contributed to the cases of COVID-19 in China and the USA, where the transmission was accentuated with the record of low temperatures and humidity of the air and suppressed with the increase of these environmental parameters. ${ }^{5}$ As they are short-term emergency analyses, the climatic seasonality of environmental parameters concerning the transmission of the virus between hosts was not performed but considered. Researches that aims to enhance the studies of a range of environmental parameters that may be related to transmission, contributes to reduce uncertainties about which environmental characteristics may favor the dissemination and contagion among inhabitants of urban centers. ${ }^{11}$ Presciently, the WHO judgment that we would be living a global pandemic and that the COVID-19 virus could be airborne was important for the development of biodefense strategies and their application in public health. ${ }^{12}$

The first official record of COVID-19 in South America occurred in Brazil on February 26, 2020, whose infectious process was imported. Until March 7, the confirmations of COVID-19 were imported and isolated cases, but the increase from 7 to 13 cases in $24 \mathrm{~h}$, confirmed the community transmission in the national territory. ${ }^{13}$ Brazil ended the year 2020 as the third-largest contagion center of COVID-19 in the world, with 7716405 confirmed cases and 195725 deaths, behind only the United States of America (USA) and India. ${ }^{14}$

In the region central-west of Brazil, the state of Mato Grosso accumulates at the end of December 2020, 179501 confirmed cases of COVID-19 at a lethality rate of $2.48 \%$ and totals 4272 deaths, 
according to epidemiological panel $n^{\circ} .298$ of the State Department of Health of Mato Grosso. The highest lethality rates in the state occur in the municipalities of Cuiabá and Várzea Grande, with $2.88 \%$ and $4.50 \%$, respectively, totaling 1742 deaths. ${ }^{15}$ The social distancing has been pointed out since the beginning of the COVID-19 pandemic as one of the fundamental issues in the mitigation of effective reproduction of the virus in urban centers. Nevertheless, the environmental conditions should be regarded in the evaluation of COVID-19 contagion and dissemination. Research so far developed establishing correlations between the incidence of COVID-19 and the characteristics of the environment pointed that, depending on the place of study and the period of analysis, different environmental parameters were significant. ${ }^{2,5,16}$

In addition to demographic density, environmental characteristics and regional climate seasonality can determine the evolution of the pandemic as well as limit the reproduction rate of the virus. The spatial variation of environmental parameters throughout the year can influence the evolutionary dynamics of COVID-19 cases and studies on the subject may reduce uncertainties. ${ }^{17}$ Thus, this study aims to investigate the relationship between the confirmed daily cases of COVID-19 and the environmental parameters in central South America.

\section{EXPERIMENTAL}

\section{Area of study}

The Conurbation Cuiabá - Várzea Grande is formed by the two municipalities with the highest demographic density in the state of
Mato Grosso. Cuiabá, the state capital, and the adjacent municipality, Várzea Grande, have $4,209,107 \mathrm{~km}^{2}$ of territorial extension and about 905,650 inhabitants. ${ }^{18}$ The territory is located in the geodesic center of South America, Figure 1. The definition of Cuiabá - Várzea Grande conurbation as an area of study takes into account the social dynamics existing among its inhabitants.

With a warm tropical climate, winter dry season, and summer rains, the region has a climate classification type "Aw" according to the climatic classification of Köppen. ${ }^{19,20}$

\section{Database}

In this study, environmental parameters such as temperature, precipitation, humidity, wind speed, solar radiation, active fire focus, and aerosols (gases and suspended particles), as well as the number of confirmed cases of COVID-19 were investigated to understand the relationship between the environment and the number of confirmed cases of COVID-19 in the Cuiabá - Várzea Grande conurbation, Mato Grosso.

The cases confirmed daily of COVID-19 in the Cuiabá - Várzea Grande conurbation was extracted from the platform of the Mato Grosso State Department of Health, SES - MT, managed by the Health Surveillance Secretariat (SVS) of the Ministry of Health. ${ }^{21}$ The atmospheric air composition over the city of Cuiabá was evaluated by the parameters measured by the CIMEL photometer of NASA's monitoring network, AERONET, in the CUIABÁ-MIRANDA region. ${ }^{22}$ The set of measurements used was the Sun Direct Version 3.0 algorithm and processing level 1.5, with dates such as total ozone column, nitrogen dioxide, water vapor, total aerosol at $500 \mathrm{~nm}$, fine

\section{Localization map of the Cuiabá-Várzea Grande Conurbation}

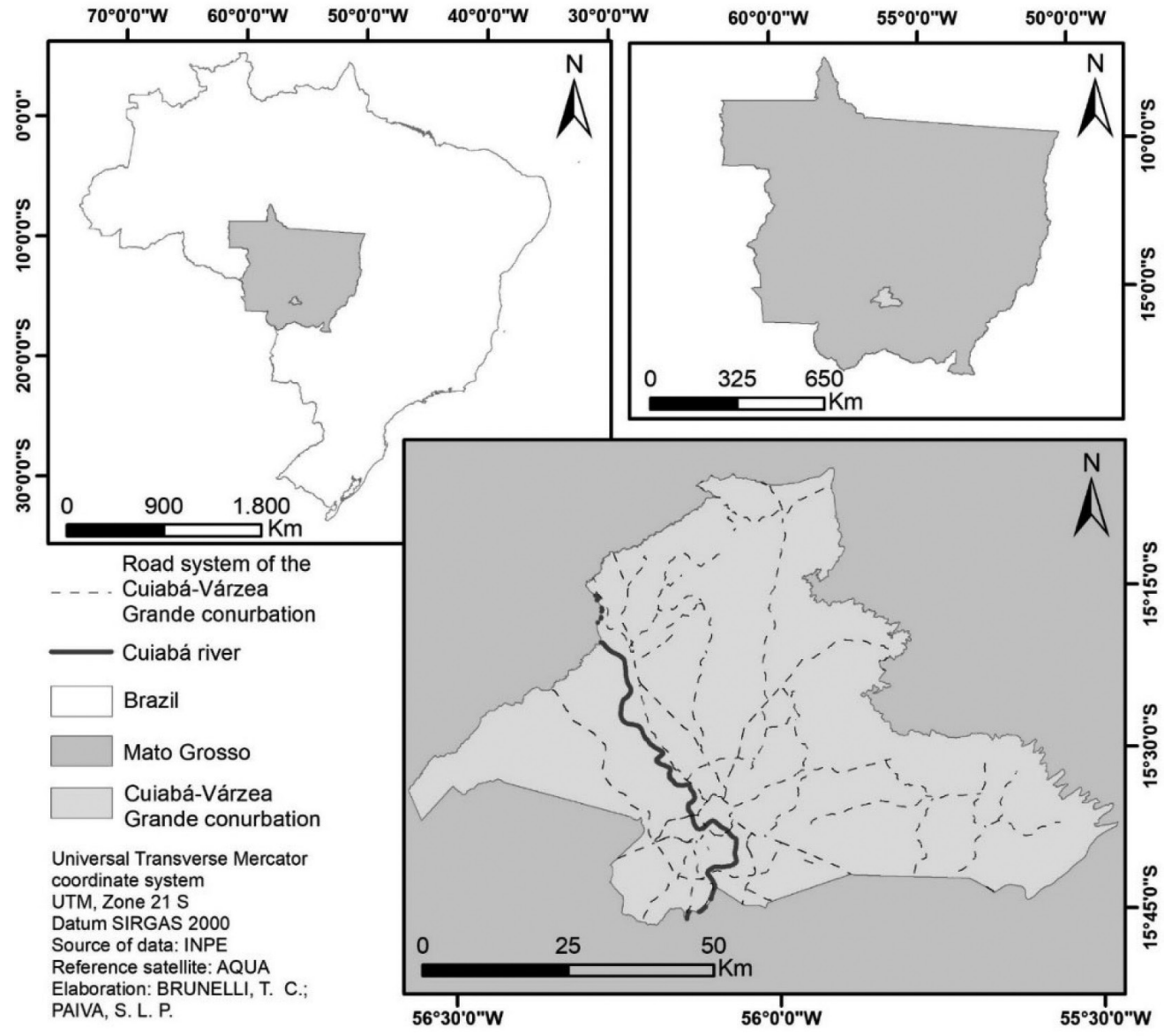

Figure 1. Map of the Cuiabá - Várzea Grande conurbation 
and coarse mode portion aerosol available between January and October 2020.

Data from fire radiative power (FRP), detected by AQUANASA reference satellites and managed by the National Institute of Space Research (INPE), were also used. ${ }^{23}$ The microclimate of the region during the period of study was analyzed by the behavior of temperature, humidity, wind, radiation, and precipitation (rain), parameters measured by the National Institute of Meteorology (INMET) in the automatic station CUIABA (A901). ${ }^{24}$ Table 1 describes the main parameters related to this study.

\section{Statistical analysis}

The relationship between COVID-19 and the environment was explored through a brief description of the parameters listed in Table 1 and subsequent application of the Spearman correlation test to evaluate whether there is a significant correlation between them. The model used to perform the correlation was chosen because the confirmed cases of COVID-19 (every $24 \mathrm{~h}$ ) throughout the study period presented a non-normal distribution by the Shapiro-Wilk test.

\section{RESULTS AND DISCUSSION}

In the initial months, the evolution of the effective contagion of COVID-19 was linear and gradual, with daily confirmations number less than 30 cases until April 30, 95 days after the beginning of symptoms of the 1st case (January 27, 2020). In January there was only 1 confirmed case, followed by 16 cases registered in February, and reaching 276 and 383 confirmed cases of COVID-19 in March and April, respectively. The month of May had a total of 2585 confirmed cases, and after 113 days (May 18, 2020), the confirmed cases of COVID-19 exceeded the rate of 100 cases every $24 \mathrm{~h}$, becoming evident the rise of contagion in the Conurbation Cuiabá - Várzea Grande. After 250 days, on October 2, 2020, the number of cases confirmed was stabilized at a rate of 100 cases per day.

The months June and July were the highest contagious, presenting the worst situations of COVID-19, accumulating 10549 and 6837 confirmed cases, respectively. From January 27 (1st day of symptomatic registration) to December 31 , the highest incidence of cases was on June 26, with 979 confirmations in $24 \mathrm{~h}$, as can be seen in Figure 2. At the end of the 339 days analyzed, 67255 confirmed cases were registered in the Cuiabá - Várzea Grande conurbation.

In the descriptive analysis of the parameters, we observed that the COVD-19 has a great instability throughout the period investigated, and can be attributed to the local dynamics of viral propagation. This analysis covered the regional environmental conditions typified in the rainy and dry seasons, which reflect the variability of some environmental parameters, such as $\mathrm{AOD}_{\text {total }}, \mathrm{AOD}_{\text {fine }}, \mathrm{AOD}_{\text {coarse }}, \mathrm{FRP}$, humidity, radiation, and precipitation, descriptive statistical analysis can be viewed in Table 2 .

To better understand how the COVID-19 relationship is to environmental parameters, the recorded data were explored in a related way. The viability of viral transmission is influenced not only between hosts but by environmental conditioning factors such as solar radiation, temperature, humidity, presence of polluting gases, and the size of aerosols available in the environment. ${ }^{26}$

The initial period of COVID-19 infections was concomitant with the rainy season, being intensified at the beginning of the dry season and mitigated in the dry-rainy transition. The average daily comportment of the set of environmental parameters can be seen

Table 1. Summary of the parameters analyzed

\begin{tabular}{|c|c|c|c|c|}
\hline Parameters & Data source & Acronym & Unit of measure & Measurement uncertainty \\
\hline Cases of Severe Acute Respiratory Syndrome by Coronavirus & SES - MT ${ }^{21}$ & COVID-19 & persons & none \\
\hline Total ozone column & AERONET 22 & $\mathrm{O}_{3}$ & $\mathrm{DU}^{\mathrm{a}}$ & \pm 0.01 \\
\hline Total column of nitrogen dioxide & AERONET 22 & $\mathrm{NO}_{2}$ & $\mathrm{DU}^{\mathrm{a}}$ & \pm 0.01 \\
\hline Total Mode of the Aerosol Optical Depth at $500 \mathrm{~nm}$ & AERONET ${ }^{22}$ & $\mathrm{AOD}_{\text {total }}$ & none & \pm 0.01 \\
\hline Fine Mode Aerosol Optical Depth at $500 \mathrm{~nm}$ & AERONET $^{22}$ & $\mathrm{AOD}_{\text {fine }}$ & none & \pm 0.01 \\
\hline Coarse Mode Aerosol Optical Depth at $500 \mathrm{~nm}$ & AERONET 22 & $\mathrm{AOD}_{\text {coarse }}$ & none & \pm 0.01 \\
\hline Total column of water vapor & AERONET 22 & $\mathrm{H}_{2} \mathrm{O}_{\text {vapor }}$ & $\mathrm{g} \mathrm{cm}^{-2}$ & $\pm 12 \%$ \\
\hline Instant temperature & INMET $^{24}$ & $\mathrm{~T}_{\mathrm{ins}}$ & ${ }^{\circ} \mathrm{C}$ & $\pm 0.2 \mathrm{C}$ \\
\hline Maximum temperature & INMET $^{24}$ & $\mathrm{~T}_{\max }$ & ${ }^{\circ} \mathrm{C}$ & $\pm 0.2 \mathrm{C}$ \\
\hline Minimum temperature & INMET $^{24}$ & $\mathrm{~T}_{\min }$ & ${ }^{\circ} \mathrm{C}$ & $\pm 0.2 \mathrm{C}$ \\
\hline Instant air relative humidity & INMET $^{24}$ & $\mathrm{U}_{\text {ins }}$ & $\%$ & $\begin{array}{c} \pm 2 \%(0 \ldots 90 \%) \\
\pm 3 \%(90 \ldots 100 \%)\end{array}$ \\
\hline Maximum relative air humidity & INMET $^{24}$ & $\mathrm{U}_{\max }$ & $\%$ & $\begin{array}{c} \pm 2 \%(0 \ldots 90 \%) \\
\pm 3 \%(90 \ldots 100 \%)\end{array}$ \\
\hline Minimum air relative humidity & INMET ${ }^{24}$ & $\mathrm{U}_{\min }$ & $\%$ & $\begin{array}{c} \pm 2 \%(0 \ldots 90 \%) \\
\pm 3 \%(90 \ldots 100 \%)\end{array}$ \\
\hline Instant atmospheric pressure & INMET ${ }^{24}$ & $\mathrm{P}_{\text {ins }}$ & $\mathrm{hPa}$ & \pm 0.3 \\
\hline Maximum atmospheric pressure & INMET ${ }^{24}$ & $\mathrm{P}_{\max }$ & $\mathrm{hPa}$ & \pm 0.3 \\
\hline Minimum atmospheric pressure & INMET $^{24}$ & $\mathrm{P}_{\min }$ & $\mathrm{hPa}$ & \pm 0.3 \\
\hline Wind speed & INMET $^{24}$ & $\mathrm{~V}$ & $\mathrm{~ms}^{-1}$ & $\pm 0.2 \%$ \\
\hline Global radiation incident & INMET $^{24}$ & $\operatorname{Rg}$ & $\mathrm{KJ} \mathrm{m}^{-2}$ & $\pm 2 \%\left(-10^{\circ} \mathrm{C}\right.$ to $\left.+40{ }^{\circ} \mathrm{C}\right)$ \\
\hline Precipitation & INMET $^{24}$ & $\mathrm{P}$ & $\mathrm{mm}$ & $\begin{array}{l} \pm 2 \%\left(0 \text { to } 250 \mathrm{~mm} \mathrm{~h}^{-1}\right) \\
\pm 3 \%\left(250 \text { to } 500 \mathrm{~mm} \mathrm{~h}^{-1}\right)\end{array}$ \\
\hline Fire radiative power & INPE $^{23}$ & FRP & $\mathrm{W}$ & $\pm 400 \mathrm{~m}$ \\
\hline
\end{tabular}

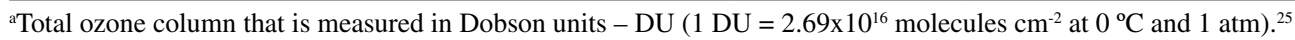




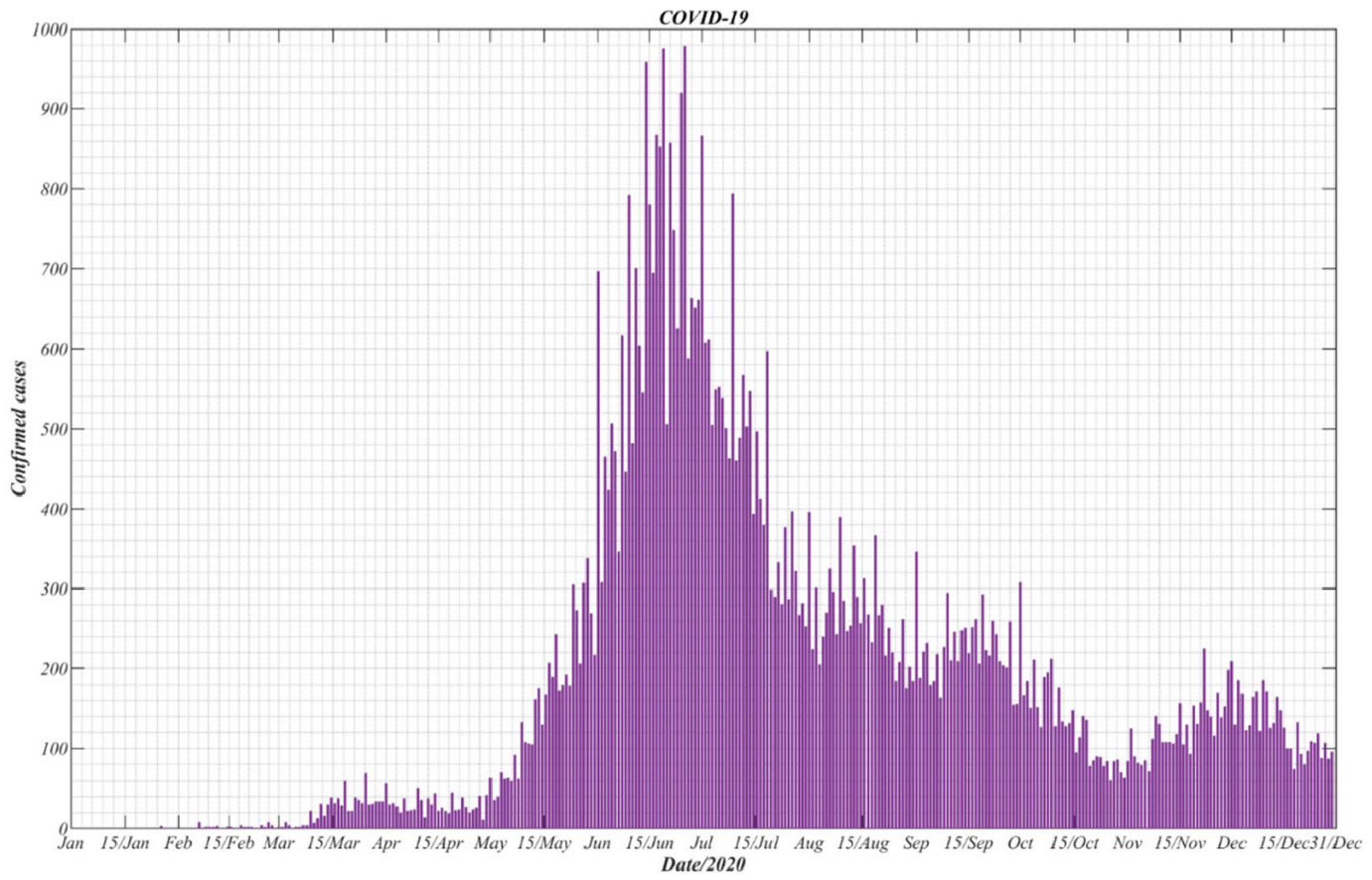

Figure 2. Cases accumulated every 24 h, confirmed from COVID-19 in the Conurbation Cuiabá - Várzea Grande

Table 2. Descriptive statistics of confirmed cases of COVID-19 and environmental parameters every $24 \mathrm{~h}$, throughout the study period

\begin{tabular}{|c|c|c|c|c|}
\hline & Average & $\begin{array}{l}\text { Standard } \\
\text { deviation }\end{array}$ & Minimum & Maximum \\
\hline COVID-19 & 198.39 & 206.79 & 0.00 & 979.00 \\
\hline $\mathrm{H}_{2} \mathrm{O}\left(\mathrm{g} \mathrm{cm}^{-2}\right)$ & 3.01 & 0.83 & 1.33 & 5.11 \\
\hline $\mathrm{O}_{3}(\mathrm{DU})$ & 262.16 & 8.97 & 250.21 & 275.24 \\
\hline $\mathrm{NO}_{2}(\mathrm{DU})$ & 0.14 & 0.03 & 0.11 & 0.20 \\
\hline $\mathrm{AOD}_{\text {total }}$ & 0.38 & 0.53 & 0.06 & 2.95 \\
\hline $\mathrm{AOD}_{\text {fine }}$ & 0.33 & 0.52 & 0.03 & 2.90 \\
\hline $\mathrm{AOD}_{\text {coarse }}$ & 0.05 & 0.03 & 0.02 & 0.33 \\
\hline $\mathrm{FRP}(\mathrm{W})$ & 48.73 & 211.49 & 0.00 & 2440.50 \\
\hline Temp. Ins. $\left({ }^{\circ} \mathrm{C}\right)$ & 28.55 & 3.28 & 14.48 & 36.64 \\
\hline Temp. Max. $\left({ }^{\circ} \mathrm{C}\right)$ & 29.24 & 3.35 & 15.03 & 37.32 \\
\hline Temp. Min. $\left({ }^{\circ} \mathrm{C}\right)$ & 27.88 & 3.21 & 14.05 & 35.90 \\
\hline Umi. Ins. (\%) & 53.87 & 15.66 & 15.62 & 88.67 \\
\hline Umi. Max. (\%) & 56.44 & 15.79 & 16.83 & 89.38 \\
\hline Umi. Min. (\%) & 51.40 & 15.57 & 14.54 & 88.05 \\
\hline Pres. Ins. (hPa) & 990.93 & 2.76 & 984.76 & 1000.79 \\
\hline Pres. Max. (hPa) & 991.23 & 2.73 & 985.15 & 1001.06 \\
\hline Pres. Min. (hPa) & 990.65 & 2.78 & 984.35 & 1000.44 \\
\hline $\mathrm{V}\left(\mathrm{ms}^{-1}\right)$ & 1.54 & 0.47 & 0.67 & 3.02 \\
\hline $\operatorname{Rg}\left(\mathrm{kJ} \mathrm{m}^{-2}\right)$ & 1535.80 & 345.63 & 293.59 & 2334.45 \\
\hline $\mathrm{P}(\mathrm{mm})$ & 2.49 & 7.29 & 0.00 & 47.60 \\
\hline
\end{tabular}

in Figure 3. In the dry period occurred the two extremes of the temperature of the year, the lowest on August 20, and the highest on October 07.

The study developed by Julian W. Tang explored the survival of viruses, bacteria, and fungi in the air, among them the coronavirus family survival related to temperature. Under relative humidity between 23 and $81 \%$, the temperature range from 7 to $8{ }^{\circ} \mathrm{C}$ was considered ideal for viral transportation in the air, decreasing under moderate temperature $\left(20.5-24^{\circ} \mathrm{C}\right)$, and with significant reduction for temperature over $30^{\circ} \mathrm{C} .{ }^{26}$ In this study, we observed that in the wet period and with low COVID contamination rates (cases reported in $24 \mathrm{~h}<100$ ), from January to April, the air temperature was about $30{ }^{\circ} \mathrm{C}$ with low variability, while the air humidity was above $50 \%$ and the wind speed was above the mean value of $1.54 \pm 0.47 \mathrm{~ms}^{-1}$.

Figure 3 presents that, during the dry season (May - October), there were many air temperature drops while there was a progressive increase in confirmations of COVID-19 (Figure 2). At the same period, the lowest relative humidity of $14.54 \%$ was recorded on September 12. Due to lipid envelopes and the reactions occurring in the surface proteins, viruses like COVID-19 present higher resistance to low relative air humidity $(15-40 \%)$ and are less resistant when exposed to higher relative humidity $(50-90 \%){ }^{26}$ Besides the low relative humidity as a viral resistance factor during the dry period, we observed that the wind speed when close to or under the mean value of $1.54 \pm 0.47 \mathrm{~ms}^{-1}$ can be associated with the number of daily cases over 100 . The wind promotes gas and particle dispersion, as well as viral loads that are in the air. We noticed that, at the beginning of the pandemic and over the wet season (until the end of April), winds above average speed contributed to a low infection rate; however, during the dry period, the wind speed was close to or above the mean value.

The atmospheric pressure can be related to the process of air compression, especially over an urban surface, which prevents the dispersion of gases, particles, and bioaerosols, such as COVID-19. The long-term mean value for atmospheric pressure was $990.93 \pm 2.76 \mathrm{hPa}$. During the dry period, we observed that the atmospheric pressure was above average, with higher variation than in the wet season. The increase of atmospheric pressure can be one of the factors that contribute to an increase in the concentration of viral loads in the air since the atmosphere size is reduced. Figures 2 and 3 show that the period with the highest number of confirmed cases was the same as when atmospheric pressure was higher than the long-term average value.

In the dry period, we can infer that the association between low temperature, low relative humidity, and low wind speed contributed to the infection of COVID-19 in the study area. Besides local factors, 

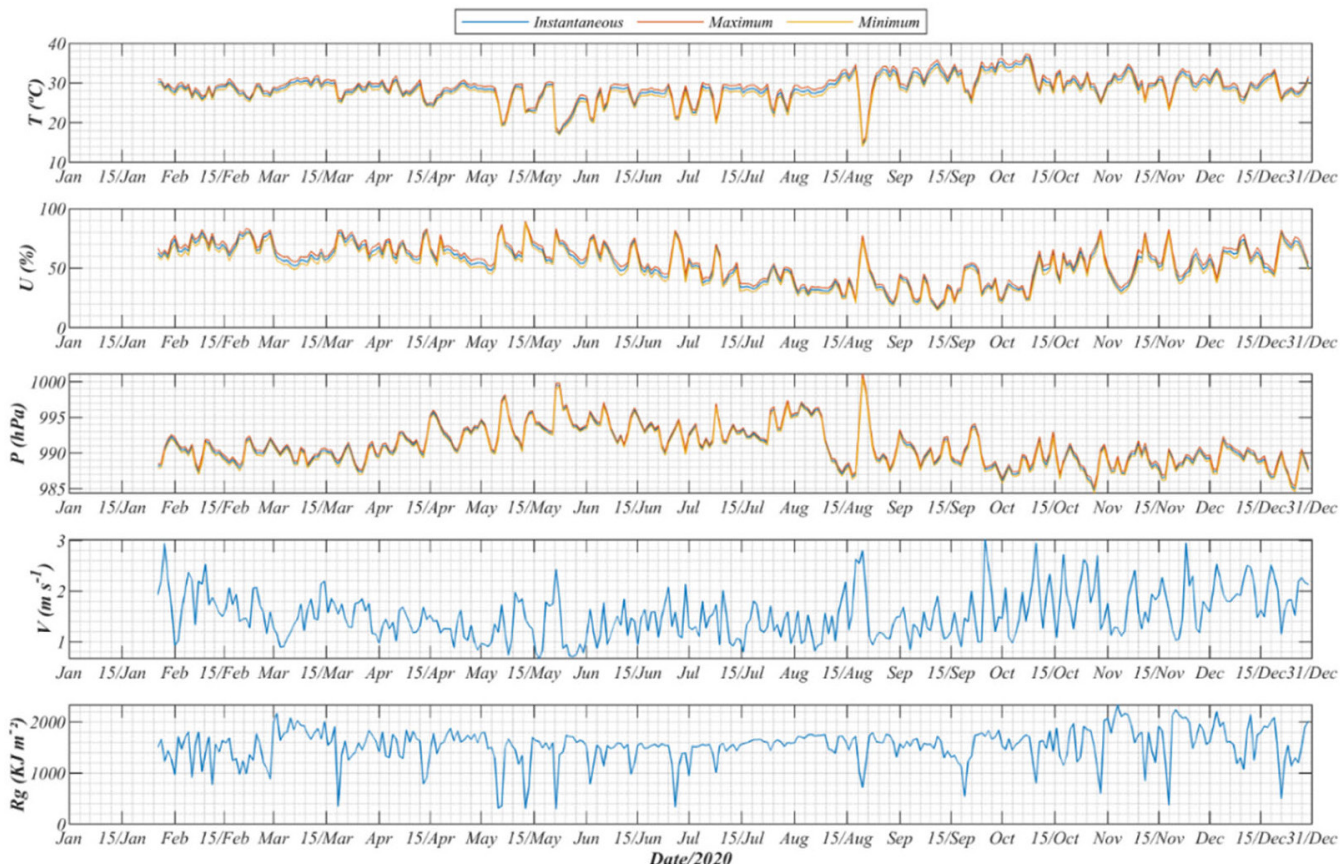

Figure 3. Average daily behavior of micrometeorological variables, $T$ - temperature, $U$ - relative humidity, $P$ - atmospheric air pressure, $V$ - wind speed, and $R g$ - incident global radiation

the action of a cold front over a large area of the country caused a thermal inversion between August 19 and 23, triggering changes in the behavior of temperature, atmospheric pressure, relative humidity, and solar radiation. ${ }^{27}$

The graph in Figure 4 shows the daily averages of the amount of water vapor present in the atmosphere the daily accumulated precipitation, and the daily fire radiative power in the Cuiabá Várzea Grande conurbation. It can be seen in Figures 2 and 4 that the period of least daily infection of COVID-19 occurred in the rainy season, with a greater disposition of water vapor in the atmosphere and precipitation. We highlight that precipitation is responsible for the deposition of humid particles, viruses, and bacteria that are suspended in the atmosphere. Thus, we infer that the rainfall events could contribute to the infection rate below 100 daily cases until the beginning of the dry season, in May.

However, when $\mathrm{H}_{2} \mathrm{O}_{\text {(vapor) }}$ stayed below $3.01 \pm 0.83 \mathrm{~g} \mathrm{~cm}^{-2}$ (mean \pm standard deviation), we observed daily cases over 100 . On the other hand, when $\mathrm{H}_{2} \mathrm{O}_{\text {(vapor) }}$ was above the average, we observed a reduction in the infection rate.

The FRP was intensified in the dry season. Records of low relative humidity, as well as the water content in the atmosphere and soil (precipitation), contribute to the spread of large forest fires and the production of smoke and soot. Smoke is one of the main vectors of air pollution in this region, the inhalation of smoke and
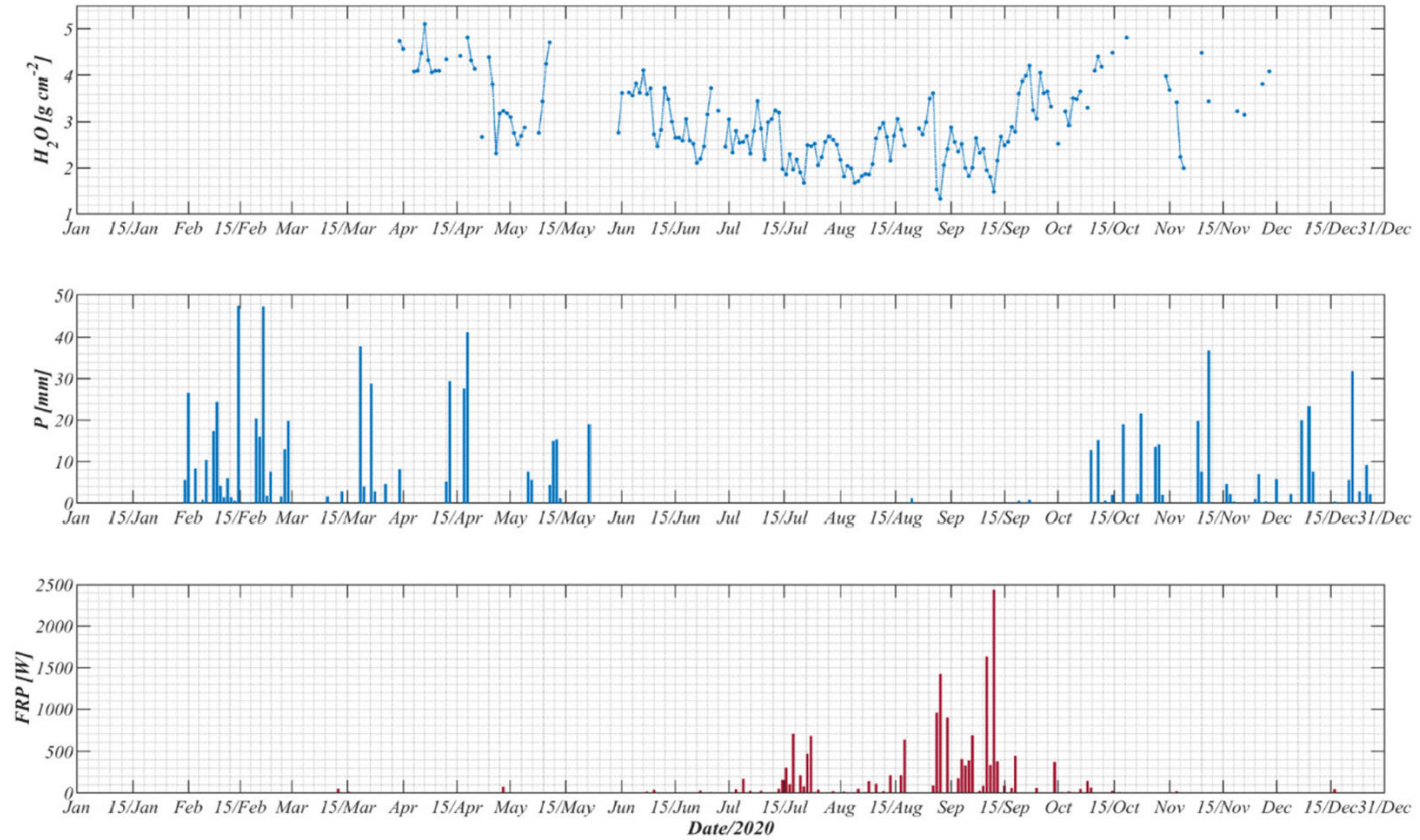

Figure 4. Daily behavior $(24 \mathrm{~h})$ of the total column of water vapor in the atmosphere $-\mathrm{H}_{2} \mathrm{O}_{(\mathrm{vapor})}$, accumulated daily rainfall $-P(\mathrm{~mm})$ and fire radiative power $-F R P(W)$ 
soot causes damage to the respiratory tract and can significantly influence COVID-19. ${ }^{28}$

The polluted atmosphere provides immense quantities and various forms of aerosol micro surfaces capable of hosting and transporting the virus over greater distances, providing a more effective contagion area. Our findings suggest that smoke pollution is associated with maintaining COVID-19 confirmations in around 100 cases every $24 \mathrm{~h}$. Figure 5 presents the location of fire foci and fire radiative power (FRP) monthly registered in the conurbation Cuiabá - Várzea Grande from Jan/01 to Dec/31 in 2020. We emphasize that regions susceptible to wildfires can be more vulnerable to COVID-19 infection.

Of the 19 environmental parameters investigated in the Spearman test, thirteen acted significantly with COVID-19, shown in Table 3 and Table 4. It is worth mentioning that the Spearman correlation is a statistical analysis that allows assessing the strength and direction of the relationship between the variables. The Spearman correlation levels can be considered weak $(0.1-0.29)$, medium $(0.3-0.49)$, and strong $(0.5-1.0) .{ }^{29}$ Air temperature, relative humidity, wind speed, incident global radiation, precipitation, the total column of water vapor, and ozone showed a negative correlation, acting as moderators in the open process of COVID-19 infection.

Among the temperatures analyzed, the minimum daily temperature showed a weak significant correlation coefficient with COVID-19 infection $(-0.13$ and p-value $=0.015)$, while the maximum and instantaneous temperature did not show a significant relationship (p-value $<0.05$ ). In the northern hemisphere $(\mathrm{HN})$, in some cities of China as well as in the USA, the air temperature was directly associated with the new cases of COVID-19. ${ }^{5}$ For the shortterm analysis (47 days), in the southeast region of Brazil in HS, the air temperature presented a result similar to that found in this study, negative correlation for Spearman's correlation test. ${ }^{29} \mathrm{We}$ infer that, in general, COVID-19 infection acts inversely proportional to the behavior of air temperature in tropical regions.

Among the environmental parameters, the maximum relative humidity was more related to COVID-19, with a correlation coefficient of -0.51 ( $p$-value $<0.01$ ), suggesting that may act in reducing the transmission rate of COVID-19. Our results agree with the generalized linear model suggested by Wang, since in China and the United States,

Fires in the Conurbation Cuiabá-Várzea Grande between January and December 2020
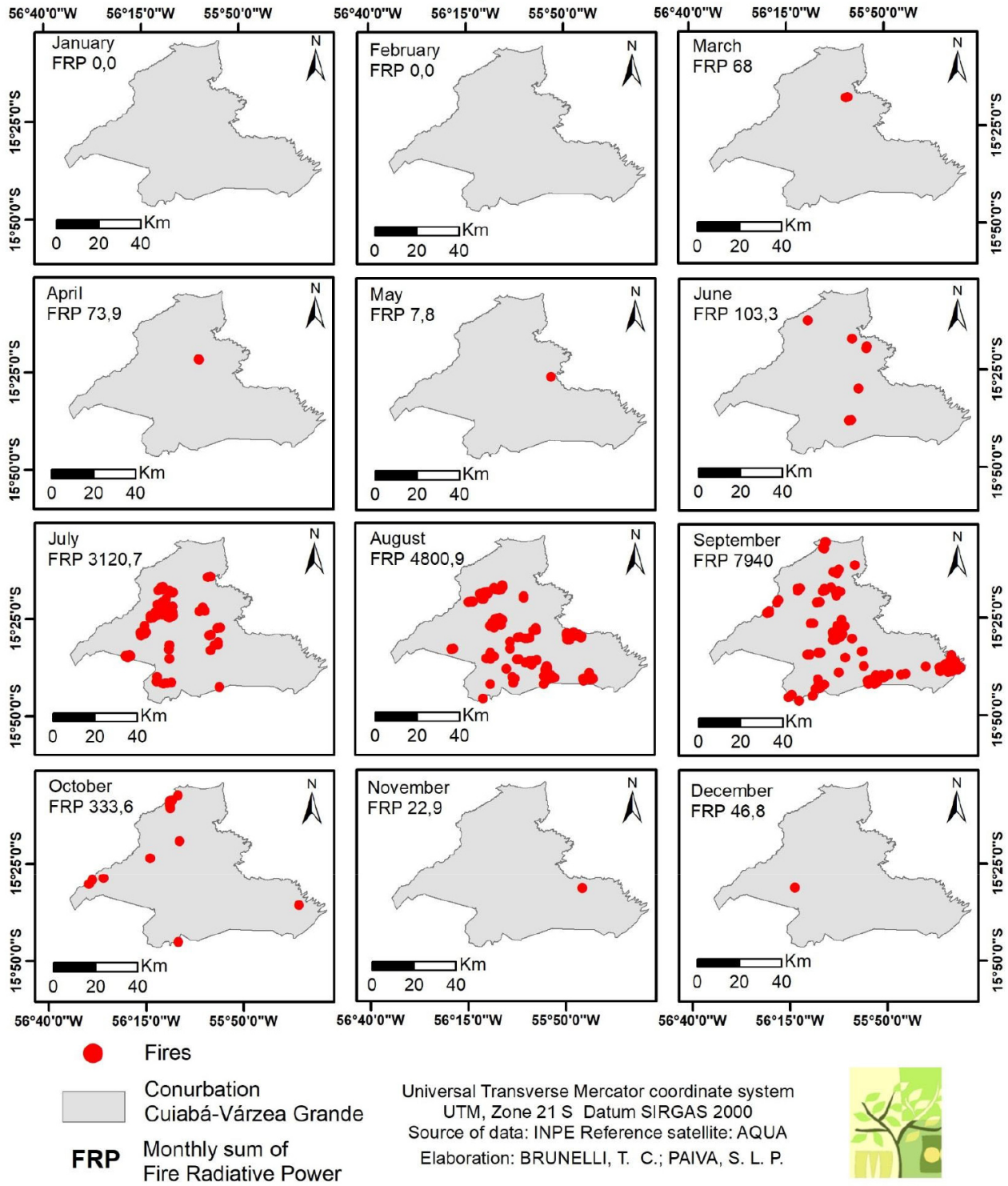

Universal Transverse Mercator coordinate system UTM, Zone $21 \mathrm{~S}$ Datum SIRGAS 2000 Source of data: INPE Reference satellite: AQUA Elaboration: BRUNELLI, T. C.; PAIVA, S. L. P.

Figure 5. Location of the outbreaks of fire and the fire radiative power (FRP) recorded monthly in the Cuiabá - Várzea Grande conurbation from January 1 to December 31, 2020 
in short term, as much as in the center of South America, in long term, high temperatures and high relative air humidity are negatively related to COVID-19 cases. Studies for other locations showed that depending on the region, the relationship between relative air humidity and COVID-19 infection could be positive or negative. ${ }^{5,17,30} \mathrm{We}$ would like to emphasize that this is the first study to perform a long-term analysis of the contribution of environmental parameters in the daily infection of COVID-19. This study presents limitations as to the discussion with other long-term analyses.

The study by Auler from multivariate analysis and canonical relationship showed that higher mean values of relative humidity in three of the five cities analyzed favored the transmission of COVID-19. However, for the cities of São Paulo and Rio de Janeiro, located in the southeastern region of Brazil, the results indicated that the increase in air humidity acted in reducing the transmission rate of COVID-19. ${ }^{31}$ In those five cities, interferences were raised in the first months of the pandemic, which can be related to the environmental parameters that characterize a climatological period, having as limiter the contribution of the annual seasonality of relative air humidity, as well as the other parameters in COVID-19 cases.

The behavior of relative humidity proves to be an important environmental parameter, suggesting that regional environmental characteristics should be taken into account in biodefense measures, especially in Brazil. Wind speed presented negatively correlated with COVID-19 infection, Table 3. A similar result was found in the research conducted in Iran, pointing that winds with high displacement speed decrease the amount of virus available in the environment. ${ }^{2}$ The expiration of people infected by COVID-19 favors the spread of COVID-19 through the air because this pathogen has reduced dimensions with the ability to coalesce in aerosol particles. ${ }^{32}$

The correlation between daily cases of COVID-19 and solar radiation was negative and significant, but with a low correlation coefficient $(-0.13$ and $\mathrm{p}$-value $<0.01)$. We observed the relation between radiation and COVID-19 cases both in $\mathrm{HN}^{2}$ and $\mathrm{HS}^{33}$ was inverse, even though the radiation levels in the subtropical region of $\mathrm{HN}$ were twice higher than in the tropical region of $\mathrm{HS}$, the correlation was significant only for the tropic. Therefore, in both short and long terms in HS, the solar radiation exposure affects the reduction in daily cases of COVID-19.

The daily accumulated rainfall depth presented a moderate and inverse correlation with the COVID-19 cases in the long term $(-0.38$ and $p$-value $<0.01)$. The worst situation of COVID-19 in the conurbation Cuiabá - Várzea Grande was registered during the dry season, as seen in Figure 2. In Table 3, we noticed that the correlation between wind speed and precipitation is positive, hence, these two parameters can act in a coupled and inverse way, fortifying the process of dispersion (wind) and deposition (precipitation) of viral loads of COVID-19 in the air. According to Table 3, the correlations between COVID-19 and atmospheric pressure (inst - max - min) were moderate, with the same values of 0.32 , and significant (p-value < 0.01 ); therefore, higher atmospheric pressure increases the infection rate of COVID-19.

The expiration of people infected with COVID-19 facilitates the propagation of the virus through the air since this pathogen has reduced dimensions with the capacity to coalesce in aerosol particles..$^{30}$ We used AOD $(500 \mathrm{~nm})$, as well as the fractions in a thin and coarse way, to evaluate the relationship of these parameters with COVID-19 in the Cuiabá - Várzea Grande conurbation, Figure 6 shows the time series of these parameters. Among aerosols, $\mathrm{AOD}_{\text {coarse }}$ $(500 \mathrm{~nm})$ showed the best correlation coefficient with COVID-19, followed by $\mathrm{AOD}_{\text {fine }}(500 \mathrm{~nm})$ and $\mathrm{AOD}_{\text {total }}(500 \mathrm{~nm})$. The $\mathrm{AOD}_{\text {coarse }}$ $(500 \mathrm{~nm})$ indicated a positive linear relationship, however, these variables did not present a significant correlation with the COVID-19 infection process, as shown in Table 4.

The variables estimated by AERONET were used because they are a representation of the numbers of aerosols available in the entire column of the atmosphere, maximizing the COVID-19 coalescence process over the aerosol. Further investigations with robust techniques are needed to investigate the relationship between COVID-19 and aerosols in central South America.

In Italy, there has been a great association between the number of people infected and the aerosols available near the surface. The increase in the concentration of coarse mode aerosols, those with up to $10 \mu \mathrm{m}$ in diameter $\left(\mathrm{PM}_{10}\right)$ and measured at $\mu \mathrm{gm}^{-3}$, accelerated the contagion of COVID-19. ${ }^{33}$ Filters analysis in the streets of Bergamo, Italy, from February to March, the apex of COVID-19 in HN, detected the presence of viral RNA confirming the coalescing process of COVID-19 in aerosols in the atmosphere. ${ }^{33}$

In the Cuiabá - Várzea Grande conurbation, the total amount of ozone in the atmosphere column presented a significant negative correlation with the COVID-19, Table 4. A similar result was obtained in Chinese provinces, where the association of COVID-19 with ozone concentration showed a significant correlation $(\mathrm{p}$-value $=$ 0.039). ${ }^{32}$ Recent results discuss the relationship between air quality, and mortality, and COVID-19. ${ }^{17,34,35}$

The total column of nitrogen dioxide showed no significant relationship with daily cases of viral infection. $\mathrm{NO}_{2}$ is an atmospheric pollutant that plays an important role in the causes of diseases in the

Table 3. The correlation coefficients of spearman's classification test between COVID-19 notifications and environmental parameters in Cuiabá-MT

\begin{tabular}{|c|c|c|c|c|c|c|c|c|c|c|c|c|c|}
\hline & COVID-19 & $\begin{array}{l}\text { Temp. } \\
\text { Ins. } \\
\left({ }^{\circ} \mathrm{C}\right)\end{array}$ & $\begin{array}{l}\text { Temp. } \\
\text { Max. } \\
\left({ }^{\circ} \mathrm{C}\right)\end{array}$ & $\begin{array}{l}\text { Temp. } \\
\text { Min. } \\
\left({ }^{\circ} \mathrm{C}\right)\end{array}$ & $\begin{array}{l}\text { Umi. } \\
\text { Ins. } \\
(\%)\end{array}$ & $\begin{array}{c}\text { Umi. } \\
\text { Max. } \\
(\%)\end{array}$ & $\begin{array}{l}\text { Umi. } \\
\text { Min. } \\
(\%)\end{array}$ & $\begin{array}{l}\text { Pres. } \\
\text { Ins. } \\
(\mathrm{hPa})\end{array}$ & $\begin{array}{l}\text { Pres. } \\
\text { Max. } \\
(\mathrm{hPa})\end{array}$ & $\begin{array}{l}\text { Pres. } \\
\text { Min. } \\
(\mathrm{hPa})\end{array}$ & $\begin{array}{c}\mathrm{V} \\
\left(\mathrm{ms}^{-1}\right)\end{array}$ & $\begin{array}{c}\mathrm{Rg} \\
\left(\mathrm{KJ} \mathrm{m}^{-2}\right)\end{array}$ & $\begin{array}{c}\mathrm{P} \\
(\mathrm{mm})\end{array}$ \\
\hline COVID-19 & 1.00 & & & & & & & & & & & & \\
\hline Temp. Ins. $\left({ }^{\circ} \mathrm{C}\right)$ & -0.10 & 1.00 & & & & & & & & & & & \\
\hline Temp. Max. $\left({ }^{\circ} \mathrm{C}\right)$ & -0.07 & $1.00 *$ & 1.00 & & & & & & & & & & \\
\hline Temp. Min. $\left({ }^{\circ} \mathrm{C}\right)$ & $-0.13 * *$ & $1.00 *$ & $0.99 *$ & 1.00 & & & & & & & & & \\
\hline Umi. Ins. (\%) & $-0.50 *$ & $-0.62 *$ & $-0.65 *$ & $-0.60 *$ & 1.00 & & & & & & & & \\
\hline Umi. Max. (\%) & $-0.51 *$ & $-0.61 *$ & $-0.64 *$ & $-0.59 *$ & $1.00 *$ & 1.00 & & & & & & & \\
\hline Umi. Min. (\%) & $-0.50 *$ & $-0.63 *$ & $-0.65 *$ & $-0.60 *$ & $1.00 *$ & $1.00 *$ & 1.00 & & & & & & \\
\hline Pres. Ins. (hPa) & $0.32 *$ & $-0.66 *$ & $-0.65 *$ & $-0.68 *$ & $0.18 *$ & $0.17 *$ & $0.19 *$ & 1.00 & & & & & \\
\hline Pres.Max. (hPa) & $0.32 *$ & $-0.66 *$ & $-0.65 *$ & $-0.67 *$ & $0.19 *$ & $0.18 *$ & $0.19 *$ & $1.00 *$ & 1.00 & & & & \\
\hline Pres. Min. (hPa) & $0.32 *$ & $-0.66 *$ & $-0.65 *$ & $-0.67 *$ & $0.18 *$ & $0.17 *$ & $0.18 *$ & $1.00 *$ & $1.00 *$ & 1.00 & & & \\
\hline $\mathrm{V}\left(\mathrm{ms}^{-1}\right)$ & $-0.19 *$ & $0.17 *$ & $0.15 *$ & $0.19 *$ & $0.14 * *$ & $0.13 * *$ & $0.14 * *$ & $-0.38 *$ & $-0.37 *$ & $-0.38 *$ & 1.00 & & \\
\hline $\operatorname{Rg}\left(\mathrm{kJ} \mathrm{m}^{-2}\right)$ & $-0.13 *$ & $0.47 *$ & $0.46 *$ & $0.45 *$ & $-0.39 *$ & $-0.38 *$ & $-0.39 *$ & $-0.20 *$ & $-0.20 *$ & $-0.20 *$ & $-0.08 * *$ & 1.00 & \\
\hline $\mathrm{P}(\mathrm{mm})$ & $-0.38 *$ & $-0.24 *$ & $-0.24 *$ & $-0.23 *$ & $0.52 *$ & $0.53 *$ & $0.51 *$ & $-0.13 * *$ & $-0.13 * *$ & $-0.14 * *$ & $0.29 *$ & $-0.36 *$ & 1.00 \\
\hline
\end{tabular}

$*$ p-value $<0.01$ and $* *$ p-value $<0.05$. 

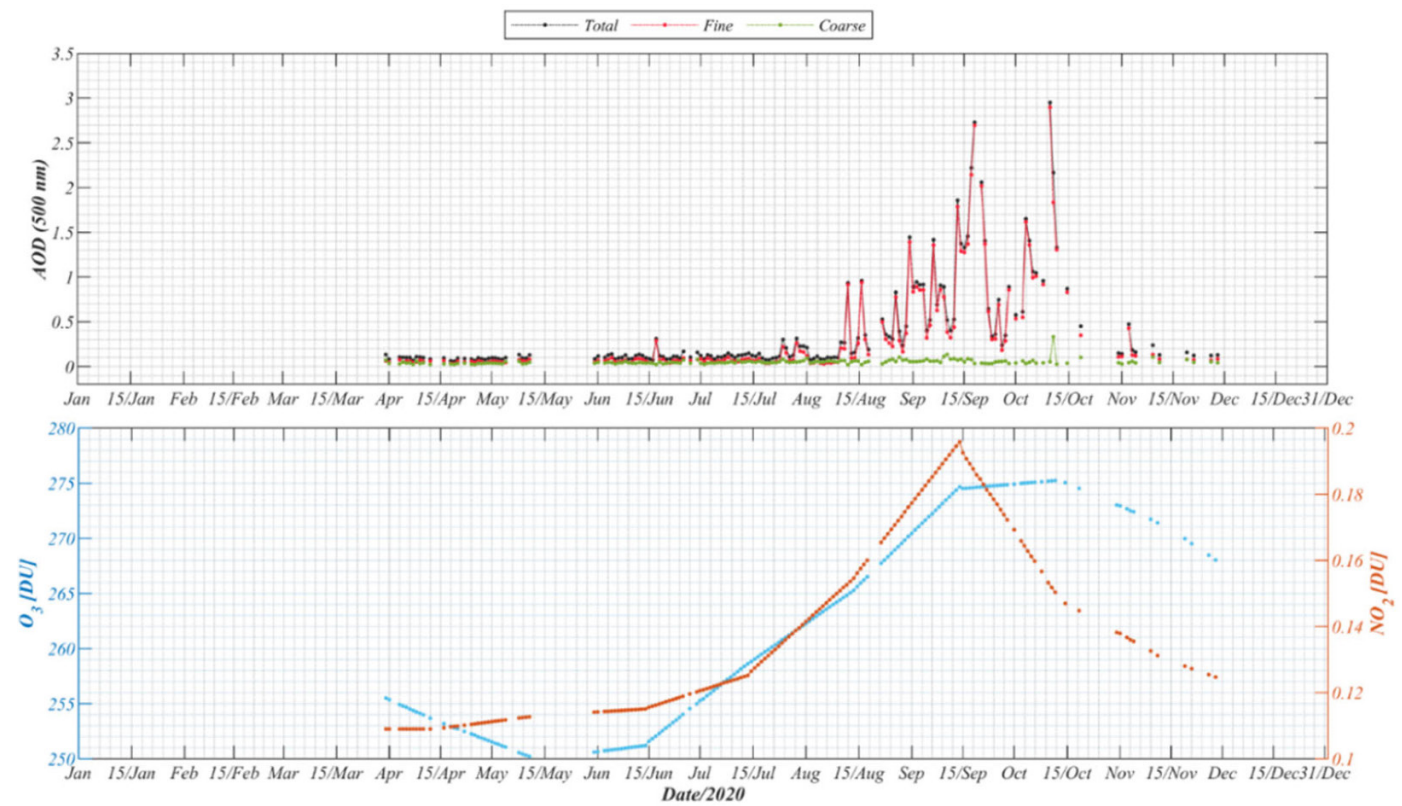

Figure 6. Average values (every $24 \mathrm{~h}$ ) of Aerosol Optical Depth - $A O D_{\text {total }}\left(\right.$ black graph), $A O D_{\text {fine }}\left(\right.$ red graph), $A O D_{\text {coarse }}$ (green graph), total column of ozone - $O_{3}$ (blue graph) and nitrogen dioxide - $\mathrm{NO}_{2}$ (orange graph)

respiratory tract, because the exposure of this pollutant promotes the mortality of the epithelial cells of the lung. ${ }^{25}$ Future analysis using surface measurements of nitrogen dioxide (instead of the total column) concentration may indicate whether or not there is a relationship with COVID-19 infection. A spatial evaluation conducted in Spain, Italy, France, and Germany showed that the population's exposure to nitrogen dioxide was one of the factors that contributed significantly to the number of deaths due to COVID-19 in the Region of Lombardy, Italy. ${ }^{16} 83 \%$ of the fatalities occurred in regions with high concentrations of $\mathrm{NO}_{2}, 15.5 \%$ in intermediate concentrations, and only $1.5 \%$ in locations with low concentrations. ${ }^{16}$

The effects of air pollution on human health have gained great importance in recent years. ${ }^{36}$ Exposure to air pollution causes damage to human health, including respiratory problems. ${ }^{28}$ The main vectors of atmospheric pollution, in addition to nitrogen dioxide and ozone, are soot, a sub-product of the action of fire. ${ }^{17}$ We evaluated the contribution of the radiative fire power (FRP) detected in the extension of the territory of the Cuiabá - Várzea Grande conurbation as shown in Figure 5, for the daily cases of COVID-19, which presented a significant correlation coefficient of 0.34 (p-value $<0.01$ ) as shown in Table 4. We infer that FRP is an environmental parameter that can be used in the containment actions of COVID-19, as it is associated with forest fires that contribute to the increase in respiratory infections. Conversely, the increase in the daily water vapor content in the atmosphere suppresses the number of daily cases of COVID-19, with a significant correlation coefficient, -0.38 ( $p$-value $<0.01$ ). Global estimates provided a prognosis that until December, in the central region of Brazil, the probability of occurrence of COVID-19 would be very low, based on the absolute humidity $\left(\mathrm{g} \mathrm{m}^{-3}\right) \cdot{ }^{17}$ Those results differ from ours, with the surface measurements of $\mathrm{H}_{2} \mathrm{O}_{\text {(vapor) }}\left(\mathrm{g} \mathrm{cm}^{-2}\right)$ in the long term. The total column of water vapor is a critical parameter to be compared and discussed due to its behavior, which is coupled to the variations of air temperature and relative humidity. It is worth mentioning that the relationship between $\mathrm{H}_{2} \mathrm{O}$ and $\mathrm{AOD}_{\text {coarse }}(500$ $\mathrm{nm}$ ) showed a correlation coefficient of -0.32 ( $\mathrm{p}$-value $<0.01$ ), which suggests an indirect relationship between coarse-mode aerosols and COVID-19 in central South America.

The influence analysis between an environmental parameter and COVID-19 cases by the Spearman correlation test has its limitation due to be possible to make interferences on the intensity and direction of the correlation between the variables. The analysis is non-causal; therefore, to set statistical prognosis of this correlation, it is necessary an association of causal factors on the propagation of COVID-19, which are beyond the environmental variables, such as demographic, socioeconomic, geographic, health, and political factors, as urban mobility and social isolation. Besides methodological limitations, we would like to emphasize that our results present limitations compared to other short-term studies since our measurements of environmental

Table 4. The correlation coefficients of spearman's classification test between COVID-19 notifications and atmospheric parameters

\begin{tabular}{|c|c|c|c|c|c|c|c|c|}
\hline & COVID-19 & $\mathrm{H}_{2} \mathrm{O}$ & $\mathrm{O}_{3}$ & $\mathrm{NO}_{2}$ & $\begin{array}{l}\mathrm{AOD}_{\text {total }} \\
(500 \mathrm{~nm})\end{array}$ & $\begin{array}{l}\mathrm{AOD}_{\text {fine }} \\
(500 \mathrm{~nm})\end{array}$ & $\begin{array}{l}\mathrm{AOD}_{\text {coarse }} \\
(500 \mathrm{~nm})\end{array}$ & RFP \\
\hline COVID-19 & 1.00 & & & & & & & \\
\hline $\mathrm{H}_{2} \mathrm{O}$ & $-0.38^{*}$ & 1.00 & & & & & & \\
\hline $\mathrm{O}_{3}$ & $-0.19^{* *}$ & -0.12 & 1.00 & & & & & \\
\hline $\mathrm{NO}_{2}$ & 0.09 & $-0.38^{*}$ & $0.87^{*}$ & 1.00 & & & & \\
\hline $\mathrm{AOD}_{\text {total }}(500 \mathrm{~nm})$ & -0.05 & 0.00 & $0.78^{*}$ & $0.79^{*}$ & 1.00 & & & \\
\hline $\mathrm{AOD}_{\text {fine }}(500 \mathrm{~nm})$ & -0.08 & 0.06 & $0.73^{*}$ & $0.74 *$ & $0.97 *$ & 1.00 & & \\
\hline $\mathrm{AOD}_{\text {coarse }}(500 \mathrm{~nm})$ & 0.10 & $-0.32 *$ & $0.41^{*}$ & $0.51 *$ & $0.48^{*}$ & $0.35^{*}$ & 1.00 & \\
\hline RFP & $0.34 *$ & $-0.49 *$ & $0.27 *$ & $0.40 *$ & $0.24 *$ & $0.21 * *$ & $0.30 *$ & 1.00 \\
\hline
\end{tabular}

$*$ p-value $<0.01$ and $* *$ p-value $<0.05$. 
parameters are referring to local long-term climatology, dry and wet seasons.

\section{CONCLUSIONS}

Based on the analysis carried out in the present study, the daily case numbers of COVID-19 for the Cuiabá - Várzea Grande conurbation showed a positive correlation significant only with two environmental parameters, atmospheric pressure (Ins., Max. and Min.) and fire radiative power (FRP). These parameters can serve as indicators of increased local transmissivity, helping to expand preventive measures to COVID-19 and other respiratory syndromes.

Relating the FRP parameter to the outbreaks of fires in the studied region and taking into account the correlation with the daily cases of COVID-19, more rigorous governmental measures and policies of environmental preservation become indispensable, aiming at reducing the numbers of fire outbreaks and thus reducing the direct influence of fires on the transmission of COVID-19.

Given the results obtained, it is noted that the increase in relative humidity and precipitation, as well as the total column of water vapor, ozone, and air temperature, contribute to the mitigation process of COVID-19. Therefore, the regulatory role of water in the transmission process of COVID-19 in central South America is highlighted.

We emphasize that although environmental parameters influence the process of transmission of COVID-19, prevention, and protection measures, such as the use of masks and social distance, continue to be more decisive in combating the virus. It must be taken into account that Brazil suffers from underreporting of the daily cases of COVID-19, which can generate a discrepancy between the real situation and the one divulged, affecting the more precise understanding of the relationship between environmental parameters and daily cases.

\section{ACKNOWLEDGMENTS}

We thank P Artaxo and J S Nogueira, as well as his team, for establishing and maintaining the site used in this investigation. Thiago R. Rodrigues was supported by the Brazilian National Council for Scientific and Technological Development $(\mathrm{CNPq})$ with Bolsa de Produtividade em Pesquisa - PQ (Grant Number 308844/2018-1).

\section{REFERENCES}

1. Taylor, S.; The psychology of pandemics: Preparing for the next global outbreak of infectious disease, Cambridge Scholars Publishing: Newcastle upon Tyne, 2019.

2. Ahmadi, M.; Sharifi, A.; Dorosti, S.; Jafarzadeh Ghoushchi, S.; Ghanbari, N.; Sci. Total Environ. 2020, 729, 138705.

3. Kim, J.; Zhang, J.; Cha, Y.; Kolitz, S.; Funt, J.; Chong, R. E.; Barrett, S.; Zeskind, B.; Kusko, R.; Kaufman, H.; ChemRxiv (2020), doi: 10.26434/ chemrxiv.12037416.v1.

4. Lu, R.; Zhao, X.; Li, J.; Niu, P.; Yang, B.; Wu, H.; Wang, W.; Song, H.; Huang, B.; Zhu, N.; Bi, Y.; Ma, X.; Zhan, F.; Wang, L.; Hu, T.; Zhou, H.; Hu, Z.; Zhou, W.; Zhao, L.; Chen, J.; Meng, Y.; Wang, J.; Lin, Y.; Yuan, J.; Xie, Z.; Ma, J.; Liu, W. J.; Wang, D.; Xu, W.; Holmes, E. C.; Gao, G. F.; Wu, G.; Chen, W.; Shi, W.; Tan, W.; Lancet 2020, 395, 565.

5. Wang, J.; Tang, K.; Feng, K.; Lin, X.; Lv, W.; Chen, K.; Wang, F.; BMJ Open 2020, 11, e043863.

6. Zhu, N.; Zhang, D.; Wang, W.; Li, X.; Yang, B.; Song, J.; Zhao, X.; Huang, B.; Shi, W.; Lu, R.; Niu, P.; Zhan, F.; Ma, X.; Wang, D.; Xu, W.; Wu, G.; Gao, G. F.; Tan, W.; N. Engl. J. Med. 2020, 382, 727.

7. de Wit, E.; van Doremalen, N.; Falzarano, D.; Munster, V. J.; Nat. Rev. Microbiol. 2016, 14, 523.
8. World Health Organization (WHO); Coronavirus disease 2019 Situation Report-52 12 March 2020, Vol. 2019.

9. van Doremalen, N.; Bushmaker, T.; Morris, D. H.; Holbrook, M. G.; Gamble, A.; Williamson, B. N.; Tamin, A.; Harcourt, J. L.; Thornburg, N. J.; Gerber, S. I.; Lloyd-Smith, J. O.; de Wit, E.; Munster, V. J.; $N$. Engl. J. Med. 2020, 382.

10. Lal, P.; Kumar, A.; Kumar, S.; Kumari, S.; Saikia, P.; Dayanandan, A.; Adhikari, D.; Khan, M. L.; Sci. Total Environ. 2020, 732, 139297.

11. Bashir, M. F.; Ma, B.; Bilal; Komal, B.; Bashir, M. A.; Tan, D.; Bashir, M.; Sci. Total Environ. 2020, 728, 138835.

12. Paules, C. I.; Marston, H. D.; Fauci, A. S.; JAMA 2020, 323, 707.

13. World Health Organization (WHO); Coronavirus Disease - 2019 (COVID-19) Situation Report - 46, 2020, p. 46.

14. Ministério da Saúde; Boletim epidemiológico especial 44; Brasília/DF, 2021.

15. Estado do Mato Grosso; Painel Epidemiológico No 298 Coronavirus/ COVID - 19 Mato Grosso, 2020

16. Ogen, Y.; Sci. Total Environ. 2020, 726, 138605.

17. Lal, P.; Kumar, A.; Kumar, S.; Kumari, S.; Saikia, P.; Dayanandan, A.; Adhikari, D.; Khan, M. L.; Sci. Total Environ. 2020, 732, 139297.

18. IBGE; Panorama - IBGE Cidades, available at https://cidades.ibge.gov. $\mathrm{br} / \mathrm{brasil} / \mathrm{mt} /$ cuiaba/panorama, accessed in June 2021.

19. Köppen, W.; Handbuch der Klimatologie, Verlag von Gebrüder Borntraeger: Berlin, 1936.

20. de Oliveira Aparecido, L. E.; da Silva Cabral de Moraes, J. R.; de Meneses, K. C.; Torsoni, G. B.; de Lima, R. F.; Costa, C. T. S.; Theor. Appl. Climatol. 2020, 142, 1133 .

21. Estado do Mato Grosso; Informes Painel Informativo COVID-19, available at http://www.saude.mt.gov.br/informe/584, accessed in June 2021.

22. AERONET - Aerosol Robotic Network, available at https://aeronet.gsfc. nasa.gov/, accessed in June 2021.

23. INPE; Programa QUEIMADAS, available at http://queimadas.dgi.inpe. $\mathrm{br} /$, accessed in June 2021.

24. INMET; TabelaEstacoes/A901, available at https://tempo.inmet.gov.br/ TabelaEstacoes/A901, accessed at June 2021.

25. Seinfeld, J. H.; Pandis, S. N.; Atmospheric Chemistry and Physics: From Air Pollution to Climate Change, $2^{\text {nd }}$ ed., Wiley: Hoboken, 2006.

26. Tang, J. W.; J. R. Soc. Interface 2009, 6 .

27. INMET; Levantamento de informações meteorológicas durante a forte onda de frio no Brasil em agosto de 2020.

28. de Oliveira, G.; Chen, J. M.; Stark, S. C.; Berenguer, E.; Moutinho, P.; Artaxo, P.; Anderson, L. O.; Aragão, L. E. O. C.; Science (80-. ). 2020, 369, 634.2.

29. Rosario, D. K. A.; Mutz, Y. S.; Bernardes, P. C.; Conte-Junior, C. A.; Int. J. Hyg. Environ. Health 2020, 229, 113587.

30. Oliveiros, B.; Caramelo, L.; Ferreira, N. C.; Caramelo, F.; medRxiv (2020), doi: 10.1101/2020.03.05.20031872.

31. Auler, A. C.; Cássaro, F. A. M.; da Silva, V. O.; Pires, L. F.; Sci. Total Environ. 2020, 729, 139090.

32. Yao, M.; Zhang, L.; Ma, J.; Zhou, L.; Sci. Total Environ. 2020, 731, 139178.

33. Setti, L.; Passarini, F.; De Gennaro, G.; Barbieri, P.; Perrone, M. G.; Borelli, M.; Palmisani, J.; Di Gilio, A.; Torboli, V.; Fontana, F.; Clemente, L.; Pallavicini, A.; Ruscio, M.; Piscitelli, P.; Miani, A.; Environ. Res. 2020, 188, 109754.

34. Bashir, M. F.; Ma, B.; Bilal; Komal, B.; Bashir, M. A.; Tan, D.; Bashir, M.; Sci. Total Environ. 2020, 728, 138835.

35. Zhu, Y.; Xie, J.; Huang, F.; Cao, L.; Sci. Total Environ. 2020, 727, 138704.

36. Brunekreef, B.; Holgate, S. T.; Lancet 2002, 360, 1233. 